\title{
Aftermath of Boko Haram violence in the Lake Chad Basin: a neglected global health threat
}

\author{
Abiodun Emmanuel Awosusi
}

To cite: Awosusi AE. Aftermath of Boko Haram violence in the Lake Chad Basin: a neglected global health threat. BMJ Global Health 2017;2:e000193. doi:10.1136/bmjgh-2016000193

Received 16 September 2016 Revised 23 November 2016 Accepted 24 November 2016

CrossMark

Centre for Tropical Medicine and Global Health, University of Oxford

\section{Correspondence to} Dr Abiodun Emmanuel Awosusi; Abiodun.awosusi@ gmail.com
The Boko Haram violence in the Lake Chad Basin has resulted in a humanitarian crisis. Since the violence began 7 years ago, more than 20000 people have been killed. ${ }^{1}$ Farms, schools, health facilities and other key infrastructure have been destroyed. Over 20 million people residing in the region which comprises parts of Cameroun, Chad, Niger and Nigeria, are severely affected by the crisis, with many unable to access essential health and social services. ${ }^{2}$

Over two million people have been displaced from their homes-more than half of them are children. ${ }^{3}$ Over $80 \%$ of these internally displaced persons reside in poor host communities with overstretched resources. One hundred and eighty-seven thousand people have fled Nigeria to Cameroun, Chad and Niger since the crisis began. Although counterinsurgency operations by the Nigerian military and the Multinational Joint Task Force have significantly weakened the insurgents, it did unearth huge humanitarian needs. Half a million children are at risk of severe acute malnutrition in the Lake Chad Basin region this year-nearly 250000 in Borno, north-east Nigeria. ${ }^{4}$ More than 4 million people are at risk of food insecurity. ${ }^{5}$

In Borno alone, more than $50 \%$ of health facilities are inaccessible and non-functional. ${ }^{6}$ The situation is similar but less severe in Adamawa, Gombe and Yobe states of Nigeria. ${ }^{7}$ In Cameroun, five of the 18 health districts in the Far North region have closed because of the violence. ${ }^{8}$ Health workers have fled for their lives. Migration of Nigerians into neighbouring Cameroun, Chad and Niger has mounted pressure on the already scarce health resources in accessible health facilities. Gaps in disease surveillance and health information management systems in the four countries have worsened the prospect of effectively tackling potential epidemics.

Camps, which house one-fifth of the internally displaced persons in Nigeria, are characterised by poor housing and hygiene conditions, inadequate food, water supply and health services. These factors, coupled with the worsening effects of climate change, heighten the risk of waterborne diseases and the likelihood of a major epidemic.

Three polio cases have been reported since early August in Jere, Gwoza and Monguno, local government areas of Borno state, after Nigeria had not reported any case of polio for more than 2 years. The Nigerian government has launched a massive polio vaccination campaign with other countries in the region with support from WHO, UNICEF and other partners. ${ }^{9}$ However, insecurity and inadequate human and financial resources hamper efforts to limit spread and eliminate polio from Africa. ${ }^{10}$

Nigeria's north east typically records poor maternal and child health indices-like the conflict-affected regions in Cameroun, Chad and Niger. Although infant mortality has dropped by $26 \%$ and under-5 mortality by $31 \%$ over the past 15 years in Nigeria, one in eight children still die before their fifth birthday. ${ }^{11}$ Infant and child mortality is generally worse in the north east than in other regions. The region recorded very poor vaccine coverage in the last three consecutive national health surveys. ${ }^{12}$ The number of stunted and wasted children is higher than national average. High rates of poverty and illiteracy with worsening effects of climate change could further aggravate the impact of health inequities in the region. ${ }^{13} 14$

Nigeria is currently in economic recession with declining national income. ${ }^{15}$ Neighbouring nations lack sufficient resources to tackle the humanitarian crisis. There is therefore an urgent need for international partners including the private sector to scale-up response in the Lake Chad Basin to reduce associated health risks. Health system resilience in the conflict-affected states is typically weak. ${ }^{16}$ Failure to act now 
could have devastating public health consequences. ${ }^{17}$ The Executive Director of the Health Emergencies Programme at WHO, Peter Salama, warned that "protracted conflict situations, such as seen in northern Nigeria-and the surrounding Lake Chad Basin countries of Cameroon, Chad and Niger-are among the greatest threats to health globally". ${ }^{6}$ Yet the international community has paid little attention.

The Nigerian government declared a food and nutrition emergency in June 2016. United Nation agencies notably WHO, UNICEF, World Food Programme, International Organization for Migration, Office of the United Nations High Commissioner for Refugees, and humanitarian agencies including Médecins Sans Frontières, International Committee of the Red Cross, and Action Against Hunger have scaled up their responses. Despite ongoing emergency response, the humanitarian response plan, particularly the health component, is grossly underfunded. ${ }^{18}$

The Ebola outbreak in West Africa offers key lessons for health response in the Lake Chad Basin. ${ }^{19}$ Delayed response costs lives and livelihood of families and nations. Weak health systems especially during protracted conflict cannot withstand the assault of deadly infectious diseases. Swift collaborative effort of national governments and development partners is vital to boldly tackle a global health threat. The cost of inaction or inadequate response in the Lake Chad basin region is high.

While emergency response is essential to save lives and reduce morbidity, early recovery and long-term development assistance is critical as violence wanes. Health system strengthening should be prioritised with integrated psychosocial and livelihood support. Measures to rebuild and strengthen health systems in the conflict-affected states will require significant health investments at all levels of government and from development partners. A key tenet of Agenda 2030 for sustainable development is to leave no one or region behind. ${ }^{20}$ There is no better time to demonstrate this commitment than now, with keen, sustained focus on the global health threat in Lake Chad Basin.

Twitter Follow Abiodun Awosusi @biodunawosusi

Competing interests AEA was Advocacy Manager at Action Against Hunger (ACF International)-Nigeria Mission.

Provenance and peer review Not commissioned; externally peer reviewed.

Data sharing statement No additional data are available.
Open Access This is an Open Access article distributed in accordance with the Creative Commons Attribution Non Commercial (CC BY-NC 4.0) license, which permits others to distribute, remix, adapt, build upon this work noncommercially, and license their derivative works on different terms, provided the original work is properly cited and the use is non-commercial. See: http:// creativecommons.org/licenses/by-nc/4.0/

\section{REFERENCES}

1. UNOCHA. About the crisis in Nigeria. New York: United Nations Office for the Coordination of Humanitarian Affairs, 2016.

2. UNOCHA. Lake Chad Basin: crisis overview. New York: United Nations Office for the Coordination of Humanitarian Affairs, 2016.

3. IOM. Displacement Tracking Matrix (DTM) Round 11 ReportAugust. Geneva: International Organization for Migration, 2016.

4. UNICEF. Children on the move, children left behind. New York: United Nations Children Fund, 2016.

5. WFP. Number of people in need of food assistance grows in NorthEastern Nigeria. Rome: United Nations World Food Programme, 2016.

6. WHO. WHO scales up response to humanitarian crisis in Nigeria Geneva: World Health Organization, 2016.

7. Ager AK, Lembani M, Mohammed A, et al. Health service resilience in Yobe state, Nigeria in the context of the Boko Haram insurgency: a systems dynamics analysis using group model building. Confl Health 2015;9:30.

8. Nouetchognou JS. Boko Haram insurgency: health and social implications for Cameroon. http://www.foretiafoundation.org/ boko-haram-insurgency-health-and-social-implications-for-cameroon/ (accessed 12 Aug 2016).

9. Adewole IF. Wild polio virus outbreak in Nigeria. Federal Ministry of Health. http://health.gov.ng/index.php/news-media/summary-ofmedia-reports/9-uncategorised/267-wild-polio-virus-outbreakin-nigeria (accessed 27 Aug 2016).

10. Bigna JJR. Polio eradication efforts in regions of geopolitical strife: the Boko Haram threat to efforts in sub-Saharan Africa. Afr Health Sci 2016;16:584-7.

11. NPC. Nigeria Demographic and Health Survey 2013. Abuja: National Population Commission. 2013.

12. NPC. Nigeria Demographic and Health Survey 2008. Abuja: National Population Commission. 2008.

13. African Development Bank. Lake Chad, a living example of the devastation climate change is wreaking on Africa. http://www.afdb. org/en/news-and-events/article/lake-chad-a-living-example-of-thedevastation-climate-change-is-wreaking-on-africa-15129/ (accessed 16 Aug 2016).

14. Obe A. Environmental degradation, climate change and conflict: the Lake Chad Basin Area. International Crisis Group. https://medium. com/the-future-of-conflict/environmental-degradation-climate-changeand-conflict-the-lake-chad-basin-area-6aec2bd9fa25\#.1pfate4dt (accessed 17 Aug 2016).

15. Umoru $\mathrm{H}$, Erunke J. Nigeria in recession, presently in tough place. Vanguard. http://www.vanguardngr.com/2016/07/nigeria-inrecession-presently-in-tough-place-adeosun (accessed 22 Aug 2016).

16. Ridde V, Lechat L, Meda IB. Terrorist attack of 15 January 2016 in Ouagadougou: how resilient was Burkina Faso's health system? BMJ Global Health 2016;1:e000056.

17. Omole $\mathrm{O}$, Welye $\mathrm{H}$, Abimbola S. Boko Haram insurgency: implications for public health. Lancet 2015;385:941.

18. UNOCHA. Humanitarian dashboard-August. New York: United Nations Office for the Coordination of Humanitarian Affairs, 2016.

19. Heymann DL, Chen L, Takemi K, et al. Global health security: the wider lessons from the West African Ebola virus disease epidemic. Lancet 2015;385:1884-901.

20. UN. Transforming our world: the 2030 Agenda for Sustainable Development. New York: United Nations, 2015. 